\title{
Synthesis, Crystal Structure and Magnetic Behaviour of Dimeric and Polymeric Gadolinium Trifluoroacetate Complexes
}

\author{
Daniela John, Alexander Rohde, and Werner Urland \\ Institut für Anorganische Chemie, Universität Hannover, Callinstr. 9, D-30167 Hannover, Germany \\ Reprint requests to Prof. Dr. W. Urland. E-mail: urland@acc.uni-hannover.de
}

Z. Naturforsch. 61b, 699 - 707 (2006); received January 27, 2006

Dedicated to Professor Wolfgang Jeitschko on the occasion of his $70^{\text {th }}$ birthday

The gadolinium(III) trifluoroacetates $\left(\left(\mathrm{CH}_{3}\right)_{2} \mathrm{NH}_{2}\right)\left[\mathrm{Gd}\left(\mathrm{CF}_{3} \mathrm{COO}\right)_{4}\right](\mathbf{1}),\left(\left(\mathrm{CH}_{3}\right)_{3} \mathrm{NH}\right)\left[\mathrm{Gd}\left(\mathrm{CF}_{3}\right.\right.$ $\left.\mathrm{COO})_{4}\left(\mathrm{H}_{2} \mathrm{O}\right)\right](2), \mathrm{Gd}\left(\mathrm{CF}_{3} \mathrm{COO}\right)_{3}\left(\mathrm{H}_{2} \mathrm{O}\right)_{3}(3)$ as well as $\mathrm{Gd}_{2}\left(\mathrm{CF}_{3} \mathrm{COO}\right)_{6}\left(\mathrm{H}_{2} \mathrm{O}\right)_{2}(\text { phen })_{3} \cdot \mathrm{C}_{2} \mathrm{H}_{5} \mathrm{OH}$ (4) (phen $=1,10$-phenanthroline) were synthesized and structurally characterized by X-ray crystallography. These compounds crystallize in the space group $P \overline{1}($ No. $2, Z=2)(\mathbf{1}, \mathbf{2}$ and $\mathbf{4})$ and $P 22_{1} / \mathrm{c}$ (No. 14, $Z=4)(3)$, respectively, with the following lattice constants 1: $a=884.9(2), b=1024.9(2)$, $c=1173.1(2) \mathrm{pm}, \alpha=105.77(2), \beta=99.51(2), \gamma=107.93(2)^{\circ} ; 2: a=965.1(1), b=1028.6(1)$, $c=1271.3(2) \mathrm{pm}, \alpha=111.83(2), \beta=111.33(2), \gamma=90.44(2)^{\circ} ; \mathbf{3}: a=919.6(2), b=1890.6(4)$, $c=978.7(2) \mathrm{pm}, \beta=113.94(2)^{\circ} ; 4: a=1286.7(8), b=1639.3(8), c=1712.2(9) \mathrm{pm}, \alpha=$ $62.57(6), \beta=84.13(5), \gamma=68.28(5)^{\circ}$. The compounds consist of $\mathrm{Gd}^{3+}$ ions which are bridged by carboxylate groups either to chains (1 and 2 ) or to dimers (3 and $\mathbf{4})$. In addition to the $\mathrm{Gd}^{3+}$ dimers, compound (4) also contains monomeric $\mathrm{Gd}^{3+}$ units. The magnetic behaviour of $\mathbf{2}$ and $\mathbf{3}$ was investigated in a temperature range of 1.77 to $300 \mathrm{~K}$. The magnetic data for these compounds indicate weak antiferromagnetic interactions.

Key words: Trifluoroacetates, Gadolinium Carboxylates, Synthesis, Crystal Structure, Magnetic Behaviour

\section{Introduction}

In the last decade the interest in the magnetic properties of polynuclear lanthanide compounds has increased [1-13]. For the magnetic investigation compounds containing $\mathrm{Gd}^{3+}$ ions often were used, as in this case ligand field interactions can be neglected in the calculation of magnetic susceptibilities [14]. To design such compounds different ligands were used as linkers between the $\mathrm{Gd}^{3+}$ ions. Here the carboxylate group was of special interest because of its different linking types to the cation [15]. Most of these compounds show antiferromagnetic interactions [16-27], but for $\mathrm{Gd}(\mathrm{sal})_{3}\left(\mathrm{H}_{2} \mathrm{O}\right) \quad\left(\mathrm{H}_{2} \mathrm{sal}=\right.$ salicylic acid $)$ [28], $\quad \mathrm{Gd}_{2}\left(\mu_{2}-\mathrm{OOCFc}\right)_{2}(\mathrm{OOCFc})_{4}(\mathrm{MeOH})_{2}\left(\mathrm{H}_{2} \mathrm{O}\right)$. $2 \mathrm{MeOH} \cdot 2 \mathrm{H}_{2} \mathrm{O}\left(\mathrm{Fc}=\left(\eta^{5}-\mathrm{C}_{5} \mathrm{H}_{5}\right) \mathrm{Fe}\left(\eta^{5}-\mathrm{C}_{5} \mathrm{H}_{4}\right)\right)$ [29], $\mathrm{Gd}\left(\mathrm{H}_{2} \mathrm{sal}\right)(\mathrm{Hsal})(\mathrm{sal}) \cdot \mathrm{H}_{2} \mathrm{O} \quad[30], \quad \mathrm{Gd}\left(\mathrm{CH}_{3} \mathrm{COO}\right)_{3}$ $\left(\mathrm{H}_{2} \mathrm{O}\right)_{2} \cdot 2 \mathrm{H}_{2} \mathrm{O}$ [31], $\mathrm{Gd}_{2}(\mathrm{mal})_{3}\left(\mathrm{H}_{2} \mathrm{O}\right)_{6} \quad\left(\mathrm{H}_{2} \mathrm{mal}=\right.$ malonic acid) [32], and $\mathrm{Gd}_{2}\left(\mathrm{H}_{2} \mathrm{O}\right)_{2}(\mathrm{DPA})_{3}\left(\mathrm{H}_{2} \mathrm{DPA}=\right.$ 2,2'-diphenic acid) [33] ferromagnetic interactions were found. Recently we reported on intramolecular ferromagnetic interactions within a dimeric unit on which intermolecular antiferromagnetic interactions are imposed $[34,35]$. In our research we modify the structural properties of $\mathrm{Gd}^{3+}$ compounds containing halogenoacetates in order to get different bridging types and as a consequence of this to get different magnetic interactions between the $\mathrm{Gd}^{3+}$ ions $[23,25-27,31,34,35]$. Up to now only few $\mathrm{Gd}^{3+}$ halogenoacetates are structurally known and not all of them were magnetically investigated [36-39].

In this work we describe the crystal structures of four different $\mathrm{Gd}^{3+}$ trifluoroacetates. We have synthesized and characterized the compounds $\left(\left(\mathrm{CH}_{3}\right)_{2} \mathrm{NH}_{2}\right)\left[\mathrm{Gd}\left(\mathrm{CF}_{3} \mathrm{COO}\right)_{4}\right] \quad(\mathbf{1}), \quad\left(\left(\mathrm{CH}_{3}\right)_{3} \mathrm{NH}\right)[\mathrm{Gd}$ $\left.\left(\mathrm{CF}_{3} \mathrm{COO}\right)_{4}\left(\mathrm{H}_{2} \mathrm{O}\right)\right]$ (2) and $\mathrm{Gd}_{2}\left(\mathrm{CF}_{3} \mathrm{COO}\right)_{6}\left(\mathrm{H}_{2} \mathrm{O}\right)_{2}$ (phen $)_{3} \cdot \mathrm{C}_{2} \mathrm{H}_{5} \mathrm{OH}$ (4) and compare their structural properties with those of the "pure" trifluoroacetate $\mathrm{Gd}\left(\mathrm{CF}_{3} \mathrm{COO}\right)_{3}\left(\mathrm{H}_{2} \mathrm{O}\right)_{3}(\mathbf{3})$. The crystal structure of $\mathbf{3}$ was solved by Jingjun et al. in 1988 [37] and the results could be confirmed. We also investigated the magnetic behaviour of $\mathbf{2}$ and $\mathbf{3}$ in the temperature range of 1.77 to $300 \mathrm{~K}$. 


\begin{tabular}{|c|c|c|c|c|}
\hline Compound & 1 & 2 & 3 & 4 \\
\hline Formula & $\mathrm{C}_{10} \mathrm{H}_{8} \mathrm{~F}_{12} \mathrm{GdNO}_{8}$ & $\mathrm{C}_{11} \mathrm{H}_{12} \mathrm{~F}_{12} \mathrm{GdNO}$ & $\mathrm{C}_{6} \mathrm{H}_{6} \mathrm{~F}_{9} \mathrm{GdO}_{9}$ & $\overline{\mathrm{C}_{50} \mathrm{H}_{34} \mathrm{~F}_{18} \mathrm{Gd}_{2} \mathrm{~N}_{6} \mathrm{O}_{15}}$ \\
\hline $\mathrm{MW}\left[\mathrm{g} \cdot \mathrm{mol}^{-1}\right]$ & 655.41 & 687.45 & 550.34 & 1611.29 \\
\hline Crystal colour & \multicolumn{4}{|c|}{ colourless } \\
\hline Crystal size $\left[\mathrm{mm}^{3}\right]$ & $0.15 \cdot 0.16 \cdot 0.53$ & $0.15 \cdot 0.22 \cdot 0.26$ & $0.26 \cdot 0.33 \cdot 0.67$ & $0.37 \cdot 0.33 \cdot 0.38$ \\
\hline Crystal system & triclinic & triclinic & monoclinic & triclinic \\
\hline Space group & $P \overline{1}$ & $P \overline{1}$ & $P 2_{1} / c$ & $P \overline{1}$ \\
\hline$a[\mathrm{pm}]$ & $884.9(2)$ & $965.1(1)$ & $919.6(2)$ & $1286.7(8)$ \\
\hline$b[\mathrm{pm}]$ & $1024.9(2)$ & 1028.6(1) & $1890.6(4)$ & $1639.3(8)$ \\
\hline$c[\mathrm{pm}]$ & 1173.1(2) & $1271.3(2)$ & $978.7(2)$ & 1712.2(9) \\
\hline$\alpha\left[^{\circ}\right]$ & $105.77(2)$ & $111.83(2)$ & 90 & $62.57(6)$ \\
\hline$\beta\left[^{\circ}\right]$ & $99.51(2)$ & $111.33(2)$ & 113.94(2) & $84.13(5)$ \\
\hline$\gamma\left[^{\circ}\right]$ & 107.93(2) & $90.44(2)$ & 90 & $68.28(5)$ \\
\hline$V\left[10^{6} \mathrm{pm}^{3}\right]$ & $937.4(3)$ & 1076.3(2) & $1555.2(5)$ & $2967.8(3)$ \\
\hline$T[\mathrm{~K}]$ & \multicolumn{4}{|c|}{293} \\
\hline$Z$ & 2 & 2 & 4 & 2 \\
\hline$D_{\text {calc. }}\left[\mathrm{g} \cdot \mathrm{cm}^{-3}\right]$ & 2.322 & 2.121 & 2.351 & 1.803 \\
\hline$F(000)$ & 622 & 658 & 1036 & 1564 \\
\hline$\theta$-Range $\left[{ }^{\circ}\right]$ & $2.37-28.22$ & $2.16-26.09$ & $2.15-25.96$ & $3.07-31.94$ \\
\hline \multirow[t]{3}{*}{$h k l$-Ranges } & $-11 \leq h \leq 11$ & $-11 \leq h \leq 11$ & $-10 \leq h \leq 10$ & $-17 \leq h \leq 15$ \\
\hline & $-13 \leq k \leq 13$ & $-12 \leq k \leq 12$ & $-23 \leq k \leq 23$ & $-20 \leq k \leq 20$ \\
\hline & $-15 \leq l \leq 15$ & $-15 \leq l \leq 15$ & $-12 \leq l \leq 12$ & $-17 \leq l \leq 22$ \\
\hline Absorption correction & - & - & numerical & - \\
\hline$\mu\left(\mathrm{Mo}-\mathrm{K}_{\alpha}\right)\left[\mathrm{mm}^{-1}\right]$ & 3.695 & 3.227 & 4.406 & 2.340 \\
\hline Max./min. transm. & - & - & $0.1258 / 0.1915$ & - \\
\hline Measured refl. & 16348 & 15413 & 21911 & 23683 \\
\hline Independent refl. & 4195 & 3971 & 2909 & 12947 \\
\hline Refl. with $I>2 \sigma(I)$ & 3781 & 3562 & 2631 & 10251 \\
\hline$R_{\text {int }}$ & 0.0406 & 0.0659 & 0.0382 & 0.0332 \\
\hline Program used & \multicolumn{4}{|c|}{ SHELXS-97 [43], SHELXL-97 [44], X-Shape [47] and X-Red [48] } \\
\hline Refinement method & \multicolumn{4}{|c|}{ full-matrix least-squares on $F^{2}$} \\
\hline Refined parameter & 291 & 318 & 251 & 826 \\
\hline $\begin{array}{l}\text { Residuals } \\
\quad \text { with } I>2 \sigma(I)^{\mathrm{a}}\end{array}$ & $\begin{array}{l}R_{1}=0.0367 \\
w R_{2}=0.0986\end{array}$ & $\begin{array}{l}R_{1}=0.0399 \\
w R_{2}=0.1036\end{array}$ & $\begin{array}{l}R_{1}=0.0307 \\
w R_{2}=0.0802\end{array}$ & $\begin{array}{l}R_{1}=0.0487 \\
w R_{2}=0.1462\end{array}$ \\
\hline Residuals (all data) ${ }^{\mathrm{a}}$ & $\begin{array}{l}R_{1}=0.0415 \\
w R_{2}=0.1076\end{array}$ & $\begin{array}{l}R_{1}=0.0463 \\
w R_{2}=0.1127\end{array}$ & $\begin{array}{l}R_{1}=0.0339 \\
w R_{2}=0.0821\end{array}$ & $\begin{array}{l}R_{1}=0.0649 \\
w R_{2}=0.1851\end{array}$ \\
\hline $\mathrm{GooF}^{\mathrm{a}}$ & 1.060 & 1.083 & 1.038 & 1.119 \\
\hline $\begin{array}{l}\text { Min./max. res. } \\
\qquad\left[10^{-6} \mathrm{e} \cdot \mathrm{pm}^{-3}\right]\end{array}$ & $-1.038 / 1.821$ & $-1.164 / 1.543$ & $-0.759 / 1.052$ & $-2.040 / 3.520$ \\
\hline CCDC number [49] & 285300 & 285301 & 280700 & 295465 \\
\hline
\end{tabular}

\begin{tabular}{|c|c|c|c|c|c|c|c|c|c|c|c|c|}
\hline \multirow{2}{*}{$\overline{\mathrm{G} c}$} & & & \multicolumn{3}{|l|}{2} & \multicolumn{3}{|l|}{3} & \multicolumn{3}{|l|}{4} & \multirow{2}{*}{$\begin{array}{l}\text { Table } 2 \text {. Selected interatomic dis- } \\
\text { tances } d / \mathrm{pm} \text { for }\left(\left(\mathrm{CH}_{3}\right)_{2} \mathrm{NH}_{2}\right)-\end{array}$} \\
\hline & $-\mathrm{O} 11$ & $240.1(4)$ & $\overline{\mathrm{Gd}}$ & $-\mathrm{O} 11$ & $235.7(5)$ & $\mathrm{Gd}$ & $-\mathrm{O} 11$ & $235.1(4)$ & $\mathrm{Gd} 1$ & $-\mathrm{O} 11$ & $236.3(4)$ & \\
\hline & $-\mathrm{O} 12$ & 241.4(4) & & -012 & $234.4(5)$ & & $-\mathrm{O} 12^{\mathrm{c}}$ & $237.6(3)$ & & -012 & 242.2(4) & {$\left[\mathrm{Gd}\left(\mathrm{CF}_{3} \mathrm{COO}\right)_{4}\right] \quad(\mathbf{1}),\left(\left(\mathrm{CH}_{3}\right)_{3}-\right.$} \\
\hline & $-\mathrm{O} 21$ & 248.3(4) & & $-\mathrm{O} 21$ & $232.6(4)$ & & $-\mathrm{O} 21$ & 246.4(4) & & -021 & 239.1(4) & $\mathrm{NH})\left[\mathrm{Gd}\left(\mathrm{CF}_{3} \mathrm{COO}\right)_{4}\left(\mathrm{H}_{2} \mathrm{O}\right)\right](2)$, \\
\hline & $-\mathrm{O} 22$ & 236.7(4) & & $-\mathrm{O} 22$ & $241.5(5)$ & & $-\mathrm{O} 22$ & 235.2(4) & & $-\mathrm{O} 22$ & 238.7(4) & $\mathrm{Gd}\left(\mathrm{CF}_{3} \mathrm{COO}\right)_{3}\left(\mathrm{H}_{2} \mathrm{O}\right)_{3} \quad(3)$ and \\
\hline & $-\mathrm{O} 31$ & 246.8(4) & & $-\mathrm{O} 31$ & $238.0(5)$ & & -031 & 237.6(4) & & -031 & 234.7(4) & $\mathrm{Gd}_{2}\left(\mathrm{CF}_{3} \mathrm{COO}\right)_{6}\left(\mathrm{H}_{2} \mathrm{O}\right)_{2}(\text { phen })_{3}$. \\
\hline & $-\mathrm{O} 32$ & $236.8(4)$ & & $-\mathrm{O} 32$ & 238.9(4) & & $-\mathrm{O} 1 \mathrm{~W}$ & 242.3(4) & & $-\mathrm{N} 1 \mathrm{~A}$ & $255.9(5)$ & $\mathrm{C}_{2} \mathrm{H}_{5} \mathrm{OH}(4)$ \\
\hline & $-\mathrm{O} 41$ & 237.1(4) & & $-\mathrm{O} 41$ & $242.8(4)$ & & $-\mathrm{O} 2 \mathrm{~W}$ & $244.0(4)$ & & $-\mathrm{N} 2 \mathrm{~A}$ & 254.4(5) & \\
\hline & $-\mathrm{O} 42$ & $239.0(4)$ & & $-\mathrm{O} 1 \mathrm{~W}$ & $246.8(5)$ & & $-\mathrm{O} 3 \mathrm{~W}$ & $239.6(4)$ & & $-\mathrm{O} 1 \mathrm{~W}$ & 236.7(4) & a $-x+1,-y,-z+1 ; \mathrm{b}-x,-y$, \\
\hline & $-\mathrm{Gd}^{\mathrm{a}}$ & $450.5(2)$ & & $-\mathrm{Gd}^{\mathrm{a}}$ & $456.0(5)$ & & $-\mathrm{Gd}^{\mathrm{d}}$ & $447.7(9)$ & & $-G d 1^{e}$ & $460.0(2)$ & $-z+1 ;{ }^{c}-x+1,-y+1,-z+2$ \\
\hline & $-\mathrm{Gd}^{\mathrm{b}}$ & $458.9(2)$ & & $-\mathrm{Gd}^{\mathrm{b}}$ & $510.5(5)$ & & & & & & & $\mathrm{d}-x,-y,-z ;{ }^{\mathrm{e}}-x+1,-y+1$, \\
\hline & & & & & & & & & $\mathrm{Gd} 2$ & -041 & $242.5(4)$ & $-z+1$ \\
\hline N1 & $-\mathrm{O} 21$ & $307.5(3)$ & N1 & $-\mathrm{O} 42$ & $273.6(4)$ & & & & & $-\mathrm{O} 51$ & 243.7(4) & \\
\hline & $-\mathrm{O} 31$ & 297.9(4) & & & & & & & & $-\mathrm{O} 52$ & 258.4(4) & \\
\hline & & & & & & & & & & -061 & $232.8(4)$ & \\
\hline & & & & & & & & & & $-\mathrm{N} 1 \mathrm{~B}$ & $261.0(5)$ & \\
\hline & & & & & & & & & & $-\mathrm{N} 2 \mathrm{~B}$ & $259.2(5)$ & \\
\hline & & & & & & & & & & $-\mathrm{N} 1 \mathrm{C}$ & $256.2(5)$ & \\
\hline & & & & & & & & & & $-\mathrm{N} 2 \mathrm{C}$ & $252.0(5)$ & \\
\hline & & & & & & & & & & $-\mathrm{O} 2 \mathrm{~W}$ & $239.0(4)$ & \\
\hline
\end{tabular}

Table 1. Crystallographic data and details for the structure determination of $\left(\left(\mathrm{CH}_{3}\right)_{2} \mathrm{NH}_{2}\right)$ $\left[\mathrm{Gd}\left(\mathrm{CF}_{3} \mathrm{COO}\right)_{4}\right](\mathbf{1}),\left(\left(\mathrm{CH}_{3}\right)_{3}-\right.$ $\mathrm{NH})\left[\mathrm{Gd}\left(\mathrm{CF}_{3} \mathrm{COO}\right)_{4}\left(\mathrm{H}_{2} \mathrm{O}\right)\right](\mathbf{2})$, $\mathrm{Gd}\left(\mathrm{CF}_{3} \mathrm{COO}\right)_{3}\left(\mathrm{H}_{2} \mathrm{O}\right)_{3}(\mathbf{3})$ and $\mathrm{Gd}_{2}\left(\mathrm{CF}_{3} \mathrm{COO}\right)_{6}\left(\mathrm{H}_{2} \mathrm{O}\right)_{2}$ (phen $)_{3}$ $\cdot \mathrm{C}_{2} \mathrm{H}_{5} \mathrm{OH}(4)$.

${ }^{a}$ Definition given in [44]. 


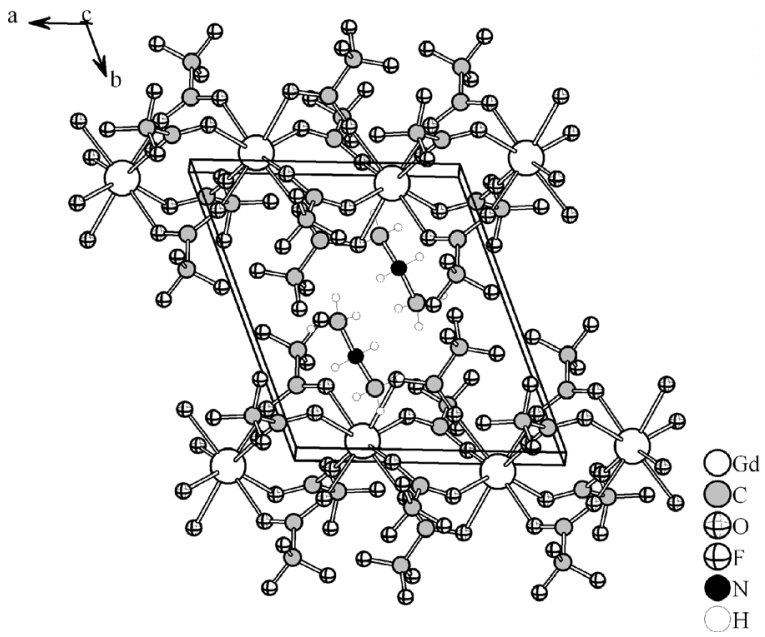

Fig. 1. Crystal structure of $\mathbf{1}$. The unit cell is shown.

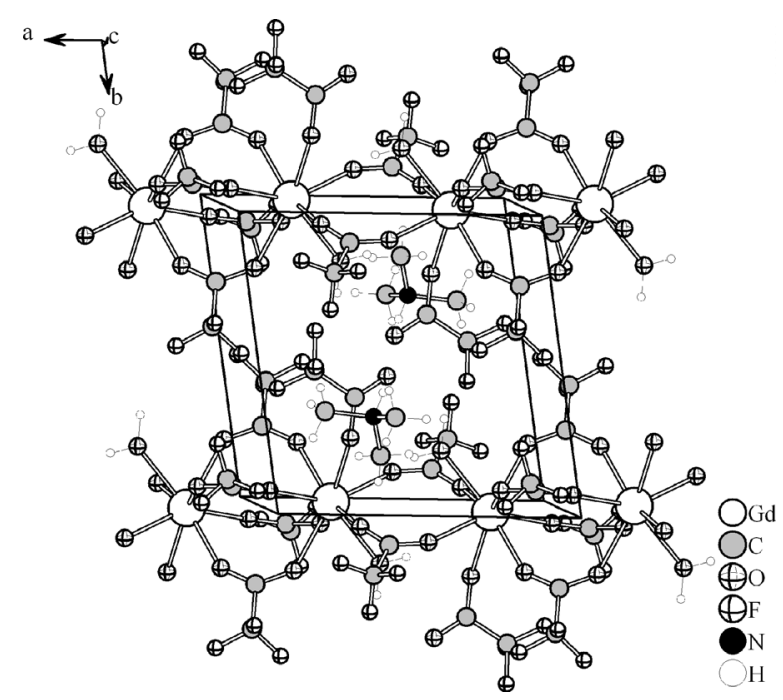

Fig. 3. Crystal structure of 2 . The unit cell is shown.

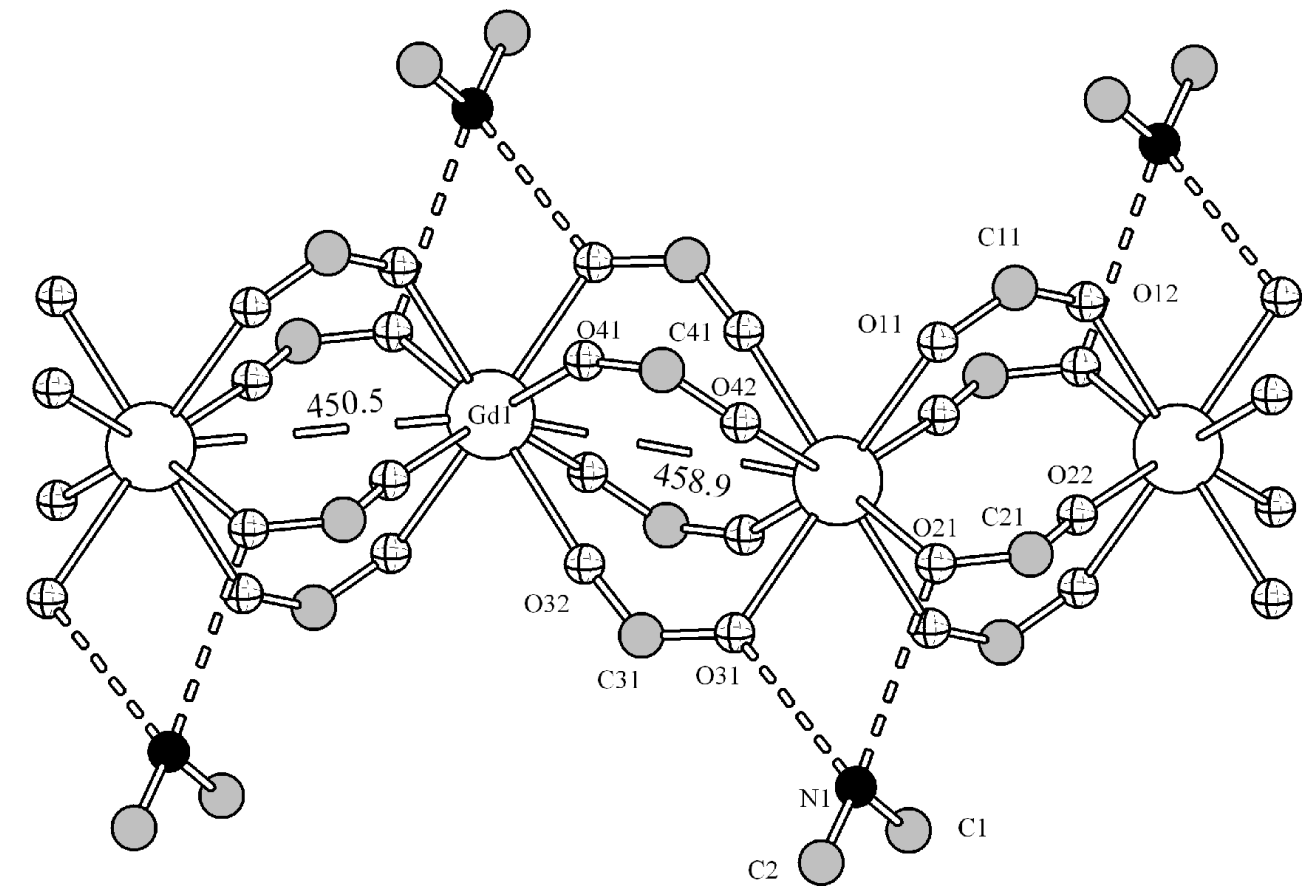

Fig. 2. Polymeric chains of $\mathbf{1}$; only Gd atoms, carboxylate groups and dimethylammonium cations are displayed. Hydrogen bonds are shown by dotted lines.

\section{Results and Discussion}

\section{Crystal structures}

Crystal data and details of the refinements for 1, 2,3 and $\mathbf{4}$ are summarized in Table 1 , selected bond distances can be found in Table 2 .
$\left(\left(\mathrm{CH}_{3}\right)_{2} \mathrm{NH}_{2}\right)\left[\mathrm{Gd}\left(\mathrm{CF}_{3} \mathrm{COO}\right)_{4}\right](\mathbf{1})$ crystallizes in the triclinic space group $P \overline{1}$ (No. $2, Z=2$ ). The crystal structure is shown in Fig. 1. The $\mathrm{Gd}^{3+}$ ion is surrounded by eight oxygen atoms originating from eight carboxylate groups with $\mathrm{Gd}-\mathrm{O}$ distances between 236.7(4) and 248.3(4) pm. The characteristic structural units are polymeric ${ }_{\infty}^{1}\left[\mathrm{Gd}\left(\mathrm{CF}_{3} \mathrm{COO}\right)_{4}\right]$ chains, running 


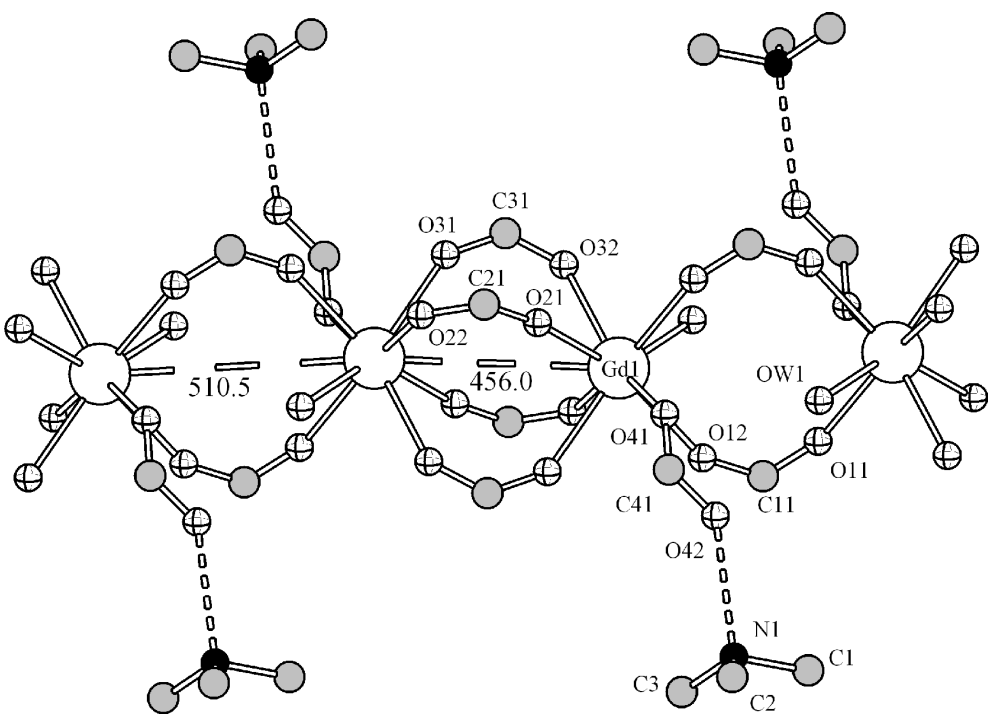

Fig. 4. Polymeric chains of 2; only Gd atoms, carboxylate groups and dimethylammonium cations are displayed. Hydrogen bonds are shown by dotted lines.

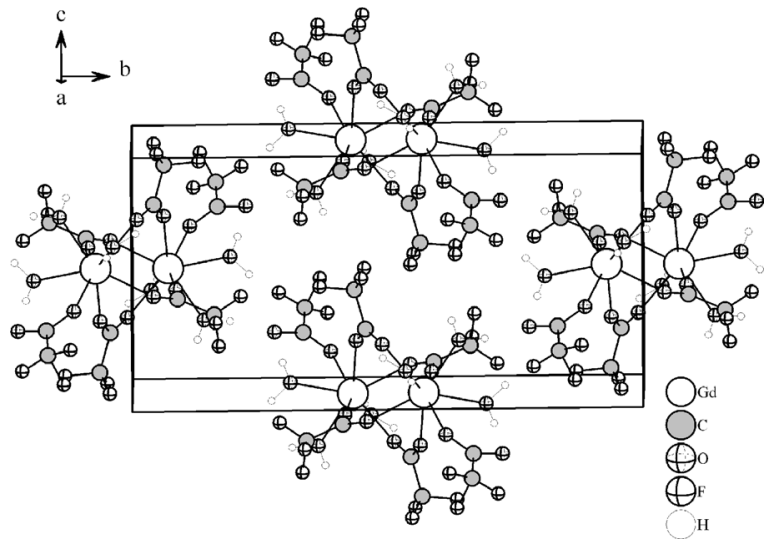

Fig. 5. Crystal structure of $\mathbf{3}$. The unit cell is shown.

along [100] (cf. Fig. 1 and 2) with bidentate bridging carboxylate groups $\left(\mu_{2}\right.$-carboxylato- $\left.\kappa^{1} O: \kappa^{1} O^{\prime}\right)$. For each Gd-Gd bridge four carboxylate groups are required. Because of the similar bridging between the $\mathrm{Gd}^{3+}$ ions there are two comparable Gd-Gd distances (450.5(2) and 458.9(2) pm). The dimethylammonium cation is bonded via hydrogen bonds to two oxygen atoms of carboxylate groups. The O-N distances are 297.9(4) and 307.5(3) pm.

The crystal structure of $\left(\left(\mathrm{CH}_{3}\right)_{3} \mathrm{NH}\right)\left[\mathrm{Gd}\left(\mathrm{CF}_{3}-\right.\right.$ $\left.\mathrm{COO})_{4}\left(\mathrm{H}_{2} \mathrm{O}\right)\right]$ (2) is shown in Fig. 3.2 crystallizes in the triclinic space group $P \overline{1}$ (No. $2, Z=2$ ). The $\mathrm{Gd}^{3+}$ ions are coordinated eightfold by seven carboxylate $\mathrm{O}$ atoms (Gd-O distances between 232.6(4) and 242.8(4) pm) and one water molecule (Gd-O distance 246.8(5) pm). The $\mathrm{Gd}^{3+}$ cations are bridged al-

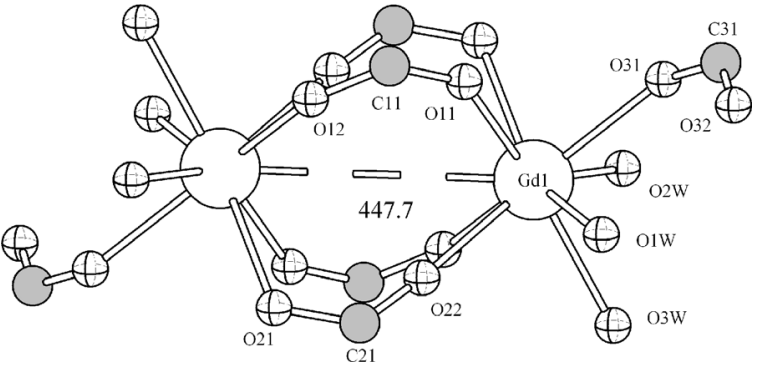

Fig. 6. Dimeric unit of $\mathbf{3}$.

ternately by two and by four carboxylate groups in a bidentate fashion $\left(\mu_{2}\right.$-carboxylato- $\left.\kappa^{1} O: \kappa^{1} O^{\prime}\right)$ to chains ( $c f$. Fig. 4). One carboxylate group is coordinated monodentately. As there are two rather different Gd-Gd distances (456.0(5) and 510.5(5) pm) the characteristic unit can be described as a chain of dimers. The trimethylammonium cation is bonded via a hydrogen bond to the non-coordinated oxygen atom of the monodentate carboxylate group (O-N distance 273.6(4) pm).

The crystal structure of $\mathrm{Gd}\left(\mathrm{CF}_{3} \mathrm{COO}\right)_{3}\left(\mathrm{H}_{2} \mathrm{O}\right)_{3}$ (3) is shown in Fig. 5. The structure is built up of $\mathrm{Gd}_{2}\left(\mathrm{CF}_{3} \mathrm{COO}\right)_{6}\left(\mathrm{H}_{2} \mathrm{O}\right)_{6}$ units (cf. Fig. 6). The $\mathrm{Gd}^{3+}$ ions are coordinated eightfold by oxygen atoms originating from five carboxylate groups (Gd-O distances: 235.1(4) -246.4(4) pm) and three water molecules (Gd-O distances: 239.6(4)-244.0(4) pm). The $\mathrm{Gd}^{3+}$ ions are connected to dimers by four of the six carboxylate groups in a $\mu_{2}$-carboxylato- $\kappa^{1} O: \kappa^{1} O^{\prime}$ bridging mode (Gd-Gd distance: 447.7(9) pm). 


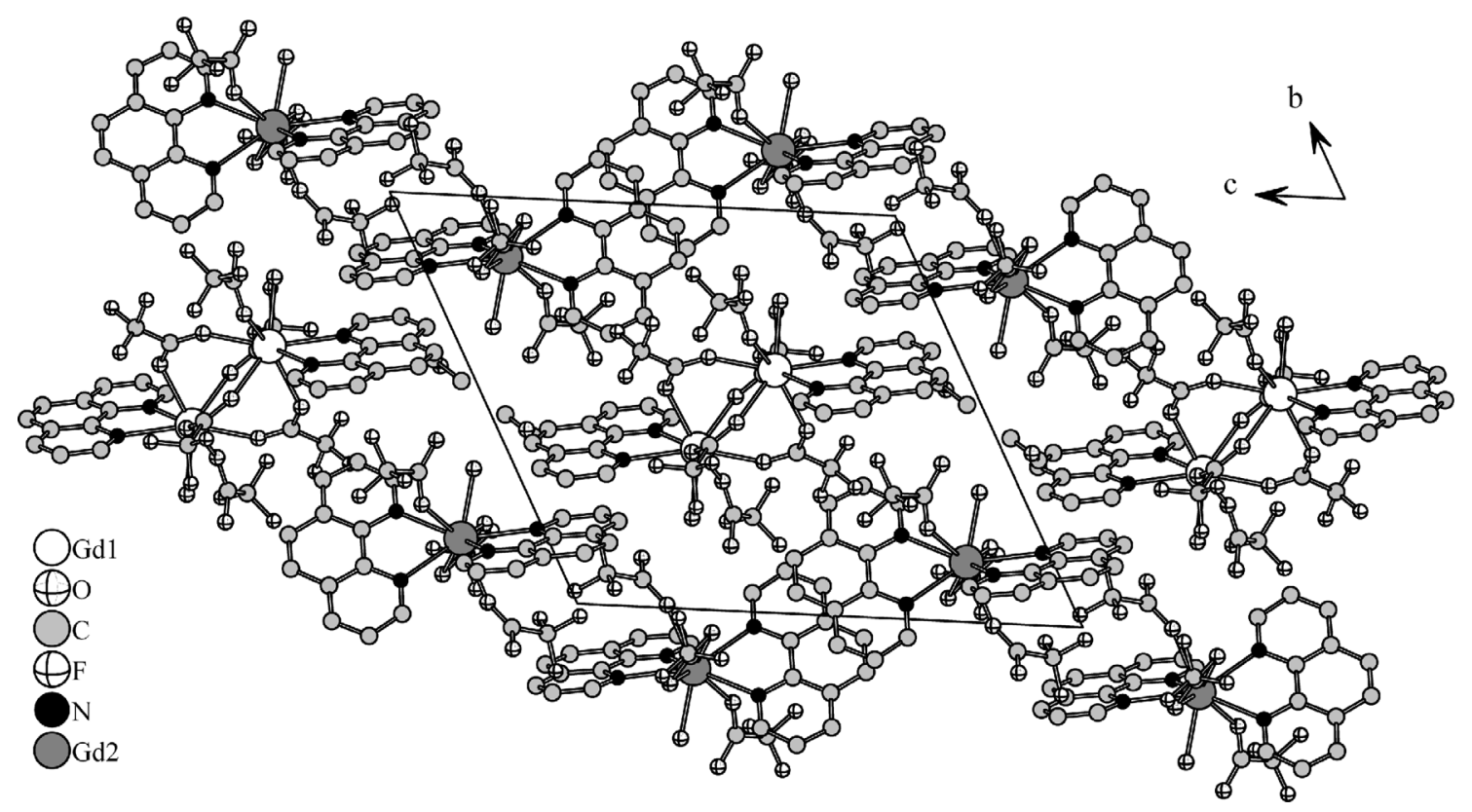

Fig. 7. Crystal structure of $\mathbf{4}$. H atoms are not displayed. The unit cell is shown.

The other carboxylate groups are connected monodentately. Compound $\mathbf{3}$ is isomorphous with $\mathrm{Ln}\left(\mathrm{CF}_{3} \mathrm{COO}\right)_{3}\left(\mathrm{H}_{2} \mathrm{O}\right)_{3}(\mathrm{Ln}=\mathrm{Pr}-\mathrm{Lu})[40]$.

The crystal structure of $\mathrm{Gd}_{2}\left(\mathrm{CF}_{3} \mathrm{COO}\right)_{6}\left(\mathrm{H}_{2} \mathrm{O}\right)_{2}$ (phen) $)_{3} \cdot \mathrm{C}_{2} \mathrm{H}_{5} \mathrm{OH}$ (4) is shown in Fig. 7. It is built up of dimeric and monomeric units ( $c f$. Fig. 8). The $\mathrm{Gd}^{3+}$ ions of the dimeric unit are coordinated eightfold by six oxygen atoms originating from five carboxylate groups and one water molecule (Gd-O distances: 234.7(4)-242.2(4) pm) and by two nitrogen atoms stemming from a 1,10-phenanthroline molecule (Gd-N distances: 254.4(5) and 255.9(5) pm). The $\mathrm{Gd}^{3+}$ ions are connected into dimers by four of the six carboxylate groups in a $\mu_{2}$-carboxylato- $\kappa^{1} O: \kappa^{1} O^{\prime}$-bridging mode (Gd-Gd distance: 460.0(2) pm). The other carboxylate groups are connected monodentately. The $\mathrm{Gd}^{3+}$ ion of the monomeric unit is coordinated ninefold by five oxygen atoms originating from four carboxylate groups and one water molecule ( $\mathrm{Gd}-\mathrm{O}$ distances: 232.8(4)-258.4(4) pm) and by four nitrogen atoms stemming from two 1,10-phenanthroline molecules (Gd-N distances: 252.0(5)-261.0(5) pm).

In all these compounds the $\mathrm{Gd}^{3+}$ ions are connected via bidentate bridged carboxylate groups to dimers and chains, respectively. The Gd-Gd distances lie between 447.7(9) and 510.5(5) pm. The rather large distance of $510.5 \mathrm{pm}$ is caused by the smaller number of the bridging carboxylate groups.

\section{Magnetic behaviour}

The short Gd-Gd distances within the compounds 2 and $\mathbf{3}$ are of interest for the study of magnetic interactions. We previously reported the magnetic behaviour of similar compounds like $\mathrm{Gd}\left(\mathrm{CClF}_{2} \mathrm{COO}\right)_{3}\left(\mathrm{H}_{2} \mathrm{O}\right)_{3}$ [25], $\mathrm{Gd}\left(\mathrm{CHF}_{2} \mathrm{COO}\right)_{3}\left(\mathrm{H}_{2} \mathrm{O}\right)_{2} \cdot \mathrm{H}_{2} \mathrm{O}$ [23] and $\left(\mathrm{NH}_{3}\right.$ $\left.\mathrm{CH}_{3}\right)\left[\mathrm{Gd}\left(\mathrm{CHCl}_{2} \mathrm{COO}\right)_{4}\right.$ ] [35]. In these compounds the $\mathrm{Gd}^{3+}$ ions are bridged by carboxylate groups also to dimers and chains in a $\mu_{2}$-carboxylato- $\kappa^{1} O: \kappa^{1} O^{\prime}$ bridging mode. The Gd-Gd distances are similar to the ones of $\mathbf{2}$ and $\mathbf{3}$.

Magnetic susceptibility data for $\mathbf{2}$ and $\mathbf{3}$ were measured in the temperature range of 1.77 to $300 \mathrm{~K}$ at magnetic fields $\left(\boldsymbol{H}^{(\mathrm{ir})}\right)$ of 500 and 1000 Oe for $\mathbf{2}$ and 300 and 1000 Oe for $\mathbf{3}$, respectively. The measured susceptibility values are field independent.

Figs. 9 and 10 show the measured effective Bohr magneton number $\left(\mu_{\text {eff }}\right.$ [41]) for 2 (Fig. 9) and 3 (Fig. 10). In both cases the r.t. values of $\mu_{\text {eff }}$ are close to the expected value for the $\mathrm{Gd}^{3+}$ ion $\left(\mu_{\text {eff }} \approx\right.$ 7.9). With the decrease of temperature, $\mu_{\text {eff }}$ decreases slowly. At $2 \mathrm{~K}$ the $\mu_{\text {eff }}$ values are about 7.5 and 7.65 , respectively. This is a typical behaviour for weak antiferromagnetic interactions. A more detailed analysis shows that the molar magnetic susceptibility can be expressed by eq. (1) with $x=J_{\mathrm{ex}} / k_{\mathrm{B}} T$, derived from the spin Hamiltonian $\hat{H}_{\mathrm{ex}}=-2 J_{\mathrm{ex}} \hat{S}_{\mathrm{Gd} 1}$. 

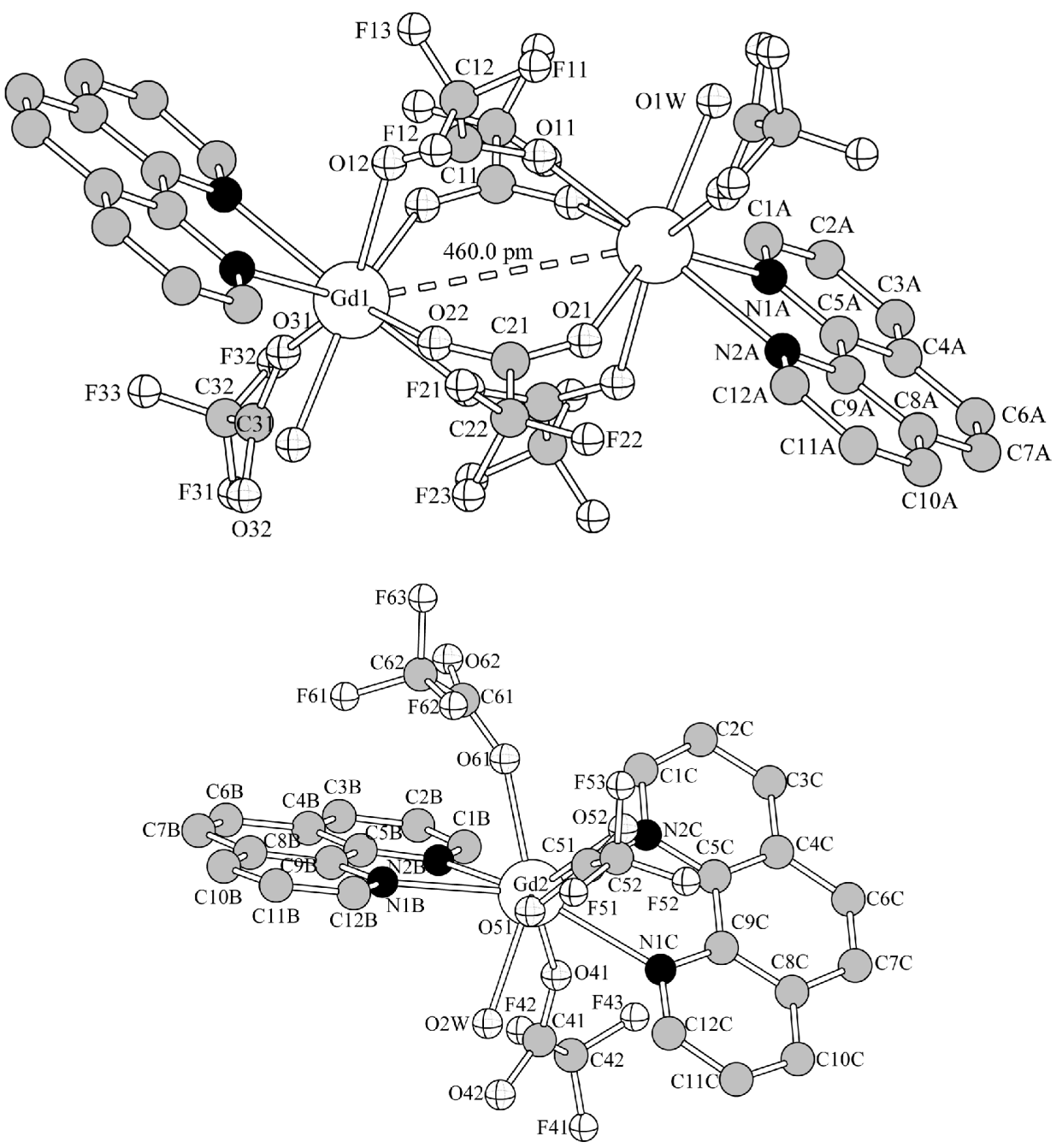

Fig. 8. Dimeric (above) and monomeric (below) unit of 4.

$$
\chi_{\mathrm{m}}^{(\mathrm{ir})}=\frac{N_{\mathrm{A}} \mu_{\mathrm{B}}^{2} g^{2}}{k_{\mathrm{B}} T} \frac{e^{2 x}+5 e^{6 x}+14 e^{12 x}+30 e^{20 x}+55 e^{30 x}+91 e^{42 x}+140 e^{56 x}}{1+3 e^{2 x}+5 e^{6 x}+7 e^{12 x}+9 e^{20 x}+11 e^{30 x}+13 e^{42 x}+15 e^{56 x}}
$$

$\hat{\boldsymbol{S}}_{\mathrm{Gd} 2}\left(S_{\mathrm{Gd} 1}=S_{\mathrm{Gd} 2}=7 / 2\right)[42]$, where $N_{\mathrm{A}}$ is the Avogadro constant, $\mu_{\mathrm{B}}$ the Bohr magneton, $g$ the Landé-factor, $k_{\mathrm{B}}$ the Boltzmann constant, $T$ the absolute temperature, and $J_{\mathrm{ex}}$ the magnetic exchange parameter. The fitting procedure for 2 leads to $J_{\mathrm{ex}}=$ $-0.0099 \mathrm{~cm}^{-1}$, with $g=1.98\left(R=8.82 \cdot 10^{-5} ; R=\right.$ $\left.\Sigma\left[\left(\mu_{\text {eff }}\right)_{\mathrm{obs}}-\left(\mu_{\text {eff }}\right)_{\text {calc }}\right]^{2} / \Sigma\left[\left(\mu_{\text {eff }}\right)_{\text {obs }}\right]^{2}\right)$, and for 3 to $J_{\mathrm{ex}}=-0.0073 \mathrm{~cm}^{-1}$, with $g=1.99\left(R=9.18 \cdot 10^{-7}\right)$. The values of $J_{\text {ex }}$ and the Gd-Gd distances $d$ in $\mathbf{2}$ and 3 are comparable with the ones for similar compounds (Table 3), where an antiferromagnetic interaction was also found for the $\mu_{2}$-carboxylato- $\kappa^{1} O: \kappa^{1} O^{\prime}$-bridging
Table 3. Magnetic exchange parameter $J_{\mathrm{ex}} / \mathrm{cm}^{-1}$ and Gd-Gd distance $d / \mathrm{pm}$ for $\mathrm{Gd}^{3+}$ carboxylates with bidentate bridging modes (* this work).

\begin{tabular}{lllc}
\hline $\mathrm{Compound}$ & $J_{\mathrm{ex}}$ & $d$ & ref. \\
\hline $\mathrm{Gd}\left(\mathrm{CHF}_{2} \mathrm{COO}\right)_{3}\left(\mathrm{H}_{2} \mathrm{O}\right)_{2} \cdot \mathrm{H}_{2} \mathrm{O}$ & -0.0125 & $445.6(2)$ & {$[23]$} \\
{$\left[\mathrm{NH}_{3} \mathrm{C}_{2} \mathrm{H}_{5}\right]\left[\mathrm{Gd}\left(\mathrm{HCCl}_{2} \mathrm{COO}\right)_{4}\right]$} & -0.010 & $453.7(7)$ & {$[34]$} \\
$\left(\left(\mathrm{CH}_{3}\right)_{3} \mathrm{NH}\right)\left[\mathrm{Gd}\left(\mathrm{CF}_{3} \mathrm{COO}\right)_{4}\left(\mathrm{H}_{2} \mathrm{O}\right)\right](2)$ & -0.0099 & $456.0(5)$ & $*$ \\
$\mathrm{Gd}_{3}\left(\mathrm{CF}_{3} \mathrm{COO}\right)_{3}\left(\mathrm{H}_{2} \mathrm{O}\right)_{3}(\mathbf{3})$ & -0.0073 & $447.7(9)$ & $*$ \\
{$\left[\mathrm{NH}_{3} \mathrm{CH}_{3}\right]\left[\mathrm{Gd}\left(\mathrm{HCCl}_{2} \mathrm{COO}\right)_{4}\right]$} & -0.007 & $451.6(7)$ & {$[35]$} \\
$\mathrm{Gd}_{\left(\mathrm{CClF}_{2} \mathrm{COO}\right)_{3}\left(\mathrm{H}_{2} \mathrm{O}\right)_{3}}$ & -0.006 & $447.6(2)$ & {$[25]$} \\
\hline
\end{tabular}

mode. Further studies on gadolinium compounds may give insight into the exchange coupling mechanism. 


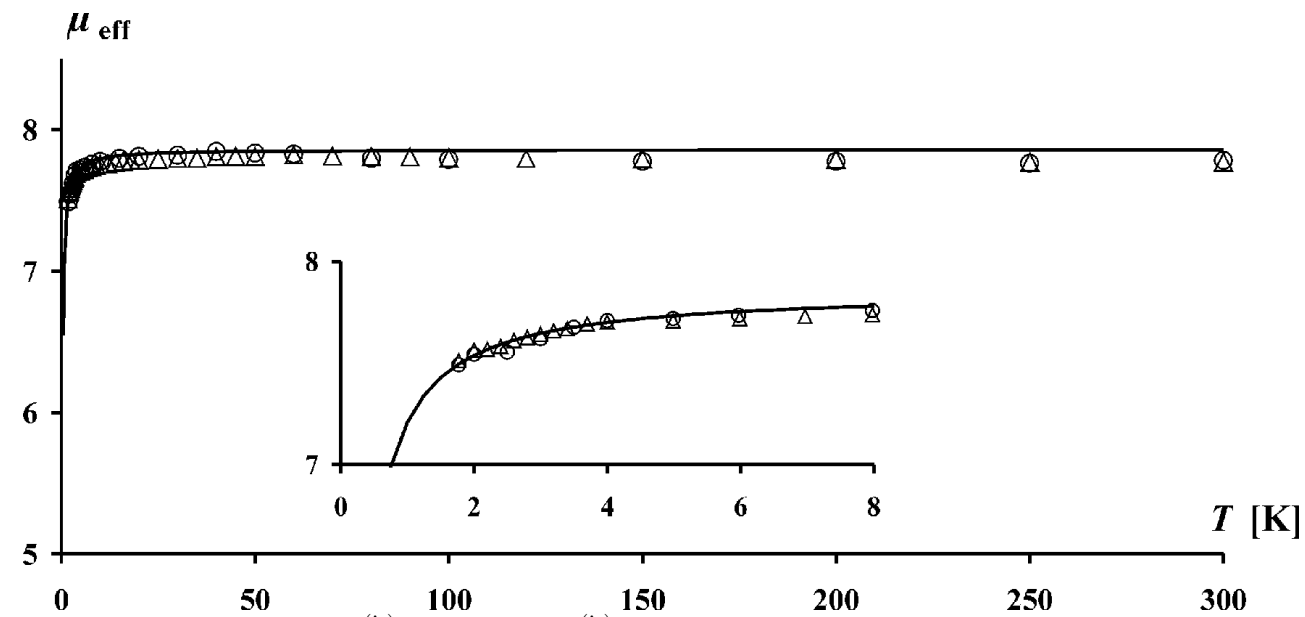

Fig. 9. Comparison of measured $\left(\Delta, \boldsymbol{H}^{(\mathrm{ir})}: 500 \mathrm{Oe} ; \circ, \boldsymbol{H}^{(\mathrm{ir})}: 1000 \mathrm{Oe}\right)$ and calculated $(-)$ effective Bohr magneton numbers for 2 .

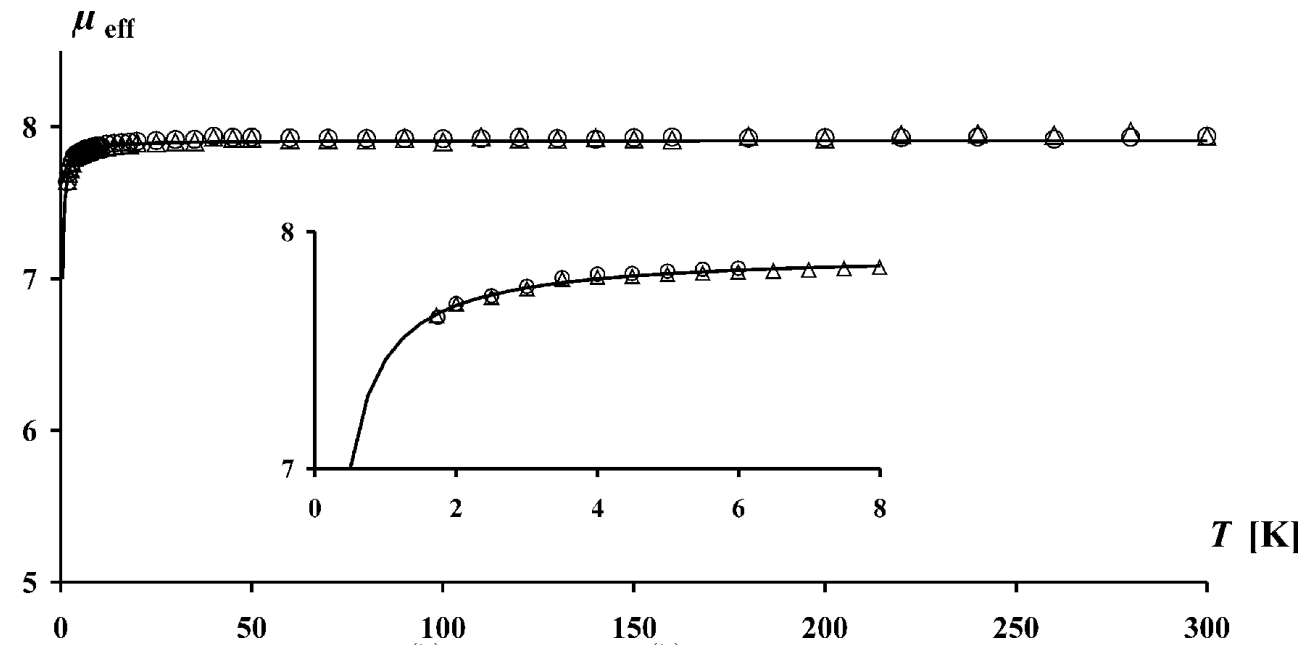

Fig. 10. Comparison of measured $\left(\Delta, H^{(\mathrm{ir})}: 300 \mathrm{Oe} ; \circ, \boldsymbol{H}^{(\mathrm{ir})}: 1000 \mathrm{Oe}\right)$ and calculated $(-)$ effective Bohr magneton numbers for 3 .

\section{Experimental Section}

\section{General}

All reagents were commercially available and used without purification $\left(\mathrm{Gd}_{2} \mathrm{O}_{3}\right.$ : Strem Chemicals, 99.9\%; trifluoroacetic acid, dimethylammonium chloride, trimethylammonium chloride: Fluka, 98\%; 1,10-phenanthroline: Aldrich, 99\%; ethanol: Sigma-Aldrich, 99.8\%). The homogeneity of all samples was investigated using X-ray powder diffraction.

\section{Preparation of $\mathbf{1}$}

Compound 1 was prepared by the reaction of $0.58 \mathrm{~g}$ $\mathrm{Gd}_{2} \mathrm{O}_{3}(3.2 \mathrm{mmol} \mathrm{Gd})$ and $1.37 \mathrm{~g}(12.01 \mathrm{mmol})$ trifluoroacetic acid in $10 \mathrm{ml} \mathrm{H}_{2} \mathrm{O}$ at about $50^{\circ} \mathrm{C}$ in a glass container. After the oxide was dissolved, the solution was allowed to cool

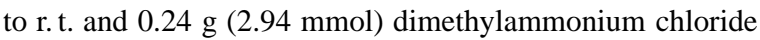
was added. After a few weeks colourless crystals had formed. The crystals are suitable for X-ray single crystal structure analysis.

\section{Preparation of $\mathbf{2}$}

Compound 2 was prepared by the reaction of $0.54 \mathrm{~g}$ $\mathrm{Gd}_{2} \mathrm{O}_{3}(2.98 \mathrm{mmol} \mathrm{Gd})$ and $1.35 \mathrm{~g}(11.84 \mathrm{mmol})$ trifluoroacetic acid in $10 \mathrm{ml} \mathrm{H}_{2} \mathrm{O}$ at about $50{ }^{\circ} \mathrm{C}$ in a glass container. After the oxide was dissolved, the solution was allowed to cool to r.t. and $0.29 \mathrm{~g}(3.03 \mathrm{mmol})$ trimethylammonium chloride was added. After few weeks colourless crystals had formed. 


\section{Preparation of $\mathbf{3}$}

$1.09 \mathrm{~g}$ ( $3 \mathrm{mmol} \mathrm{Gd}) \mathrm{Gd}_{2} \mathrm{O}_{3}$ was suspended in water $(10 \mathrm{ml})$ and $1.14 \mathrm{~g}(10 \mathrm{mmol})$ trifluoroacetic acid was added. In the solution colourless crystals formed after several days.

\section{Preparation of 4}

Compound 4 was prepared by reaction of $0.55 \mathrm{~g}$ of 3 (1 mmol Gd) and $0.36 \mathrm{~g}(1 \mathrm{mmol}) 1,10$-phenanthroline in a solution of ethanol and water (1:1). After a few days transparent, colourless, air stable crystals were obtained.

\section{$X$-ray crystallographic studies}

The intensities for all compounds were measured on a STOE imaging plate diffractometer. The data collection was carried out at r. t. The structures were solved by direct methods and were refined with anisotropic displacement parameters based on $F^{2}$ using SHELXS-97 [43] and SHELXL-97
[44] programs. The hydrogen atoms (compounds 1, 2 and 4) were positioned with idealized geometry and refined with isotropic displacement parameters. The crystal data and details of the refinement are summarized in Table 1.

\section{Magnetic measurement}

Crushed single crystals of $\mathbf{2}$ and $\mathbf{3}$ were measured with a SQUID magnetometer (MPMS5, Quantum Design) in a temperature range of 1.77 to $300 \mathrm{~K}$ at magnetic fields $\left(\boldsymbol{H}^{(\mathrm{ir})}\right)$ of 0.5 and $1 \mathrm{kOe}(2)$ and 0.3 and $1 \mathrm{kOe}(3)$, respectively. No field dependence was observed. The sample was weighed into the lid of a gelatin capsule. To evade orientation effects during the measurement, the bottom of the gelatin capsule was pressed on the sample to fix it. A second lid closed the capsule. Then the container was sewn in a plastic straw. The raw magnetic data were corrected for diamagnetism of the sample carrier and the sample, using the increments of Haberditzl [45]. The presentation of the magnetic data follows the recommendation of Hatscher et al. [46].
[1] P. Guerriero, S. Tamburini, P. A. Vigato, Inorg. Chim. Acta 189, 19 (1991).

[2] S. Liu, L. Gelmini, S. J. Rettig, R.C. Thompson, C. Orvig, J. Am. Chem. Soc. 114, 6081 (1992).

[3] W. Plass, G. Fries, Z. Anorg. Allg. Chem. 623, 1205 (1997).

[4] J.-P. Costes, A. Dupuis, J.-P. Laurent, Inorg. Chim. Acta 268, 125 (1998).

[5] J.-P. Costes, F. Dahan, A. Dupuis, S. Lagrave, J.-P. Laurent, Inorg. Chem. 37, 153 (1998).

[6] R. Hedinger, M. Ghisletta, K. Hegetschweiler, E. Tóth, A. E. Merbach, R. Sessoli, D. Gatteschi, V. Gramlich, Inorg. Chem. 37, 6698 (1998).

[7] J.-P. Costes, F. Dahan, F. Nicodème, Inorg. Chem. 40, 5285 (2001).

[8] F. Avecilla, C. Platas-Iglesias, R. Rodríguez-Cortiñas, G. Guillemot, J.-C. G. Bünzli, C. D. Brondino, C. F. G. C. Geraldes, A. de Blas, T. Rodríguez-Blas, J. Chem. Soc., Dalton Trans. 4658 (2002).

[9] H. Zhao, M. J. Bazile, J. R. Galán-Mascarós, K. R. Dunbar, Angew. Chem. Int. Ed. 42, 1015 (2003).

[10] R. Gheorghe, V. Kravtsov, Y. A. Simonov, J.-P. Costes, Y. Journaux, M. Andruh, Inorg. Chim. Acta 357, 1613 (2004).

[11] A. Wun, F.-K. Zheng, W.-T. Chen, L.-Z. Cai, G.-C. Guo, J.-S. Huang, Z.-C. Dong, Y. Takano, Inorg. Chem. 43, 4839 (2004).

[12] S. Wörl, I. O. Fritsky, D. Hellwinkel, H. Pritzkow, R. Krämer, Eur. J. Inorg. Chem. 759 (2005).

[13] Z. He, E. Q. Gao, Z.-M. Wang, C.-H. Yan, M. Kurmoo, Inorg. Chem. 44, 862 (2005).
[14] S. T. Hatscher, W. Urland, J. Solid State Chem. 176, 288 (2003)

[15] A. Ouchi, Y. Suzuki, Y. Ohki, Y. Koizumi, Coord. Chem. Rev. 92, 29 (1988).

[16] A. Panagiotopoulos, T. F. Zafiropoulos, S. P. Perlepes, E. Bakalbassis, I. Masson-Ramade, O. Kahn, A. Terzis, C. P. Raptopoulou, Inorg. Chem. 34, 4918 (1995).

[17] A. Rizzi, R. Baggio, R. Calvo, M. T. Garland, O. Peña, M. Perec, Inorg. Chem. 40, 3623 (2001).

[18] X. Li, R. Cao, D. Sun, Q. Shi, M. Hong, Y. Liang, Inorg. Chem. Commun. 5, 589 (2002).

[19] S. Y. Niu, J. Jin, X. L. Jin, Z.Z. Yang, Solid State Sci. 4, 1103 (2002).

[20] D. Sun, R. Cao, Y. Liang, Q. Shi, M. Hong, J. Chem. Soc., Dalton Trans. 1847 (2002).

[21] A. W.-H. Lam, W.-T. Wong, S. Gao, G. Wen, X.-X. Zhang, Eur. J. Inorg. Chem. 149 (2003).

[22] A. Rizzi, R. Baggio, M. T. Garland, O. Peña, M. Perec, Inorg. Chim. Acta 353, 315 (2003).

[23] A. Rohde, S. T. Hatscher, W. Urland, J. Alloys Compd. 374, 137 (2004).

[24] A. M. Atria, R. Baggio, M. T. Garland, J. C. Muñoz, O. Peña, Inorg. Chim. Acta 357, 1997 (2004).

[25] A. Rohde, W. Urland, Z. Anorg. Allg. Chem. 630, 2434 (2004).

[26] D. John, W. Urland, Eur. J. Inorg. Chem. 4489 (2005).

[27] D. John, W. Urland, Z. Anorg. Allg. Chem. 631, 2635 (2005).

[28] J.-P. Costes, J.-M. Clemente-Juan, F. Dahan, F. Nicodème, M. Verelst, Angew. Chem. Int. Ed. 41, 323 (2002). 
[29] H. Hou, G. Li, L. Li, Y. Zhu, X. Meng, Y. Fan, Inorg. Chem. 42, 428 (2003).

[30] J.-P. Costes, J.-M. Clemente-Juan, F. Dahan, F. Nicodème, Dalton Trans. 1272 (2003).

[31] S. T. Hatscher, W. Urland, Angew. Chem. Int. Ed. 42, 2862 (2003).

[32] M. Hernández-Molina, C. Ruiz-Pérez, T. López, F. Lloret, M. Julve, Inorg. Chem. 42, 5456 (2003).

[33] A. Thirumurugan, S. K. Pati, M. A. Green, S. Natarajan, Z. Anorg. Allg. Chem. 630, 579 (2004).

[34] A. Rohde, W. Urland, J. Alloys Compd. 408-412, 618 (2006).

[35] A. Rohde, W. Urland, Z. Anorg. Allg. Chem. 631, 417 (2005).

[36] Y. Sugita, A. Ouchi, Bull. Chem. Soc. Jpn. 60, 171 (1987).

[37] Z. Jingjun, Z. Siyuan, M. Xiuqin, W. Gecheng, H. Ninghai, J. Zhongsheng, Yingyong Huaxue 5, 30 (1988).

[38] A. Rohde, W. Urland, Z. Anorg. Allg. Chem. 629, 2069 (2003).

[39] A. Rohde, D. John, W. Urland, Z. Kristallogr. 220, 177 (2005).

[40] P.C. Junk, C. J. Kepert, L. Wei-Min, B. W. Skelton, A. H. White, Aust. J. Chem. 52, 459 (1999).
[41] $\mu_{\text {eff }}=2.8279\left(T \chi_{\mathrm{m}}{ }^{(\mathrm{ir})}\right)^{1 / 2}$

[42] H. Lueken, Magnetochemie, Teubner, Stuttgart (1999).

[43] G. M. Sheldrick, SHELXS-97, A Program for Crystal Structure Solution; University of Göttingen: Göttingen, Germany (1990).

[44] G. M. Sheldrick, SHELXL-97, A Program for the refinement of crystal structures from diffraction data; University of Göttingen: Göttingen, Germany (1997).

[45] W. Haberditzl, Angew. Chem. Int. Ed. Engl. 5, 288 (1966).

[46] S. T. Hatscher, H. Schilder, H. Lueken, W. Urland, Pure Appl. Chem. 77, 497 (2005).

[47] STOE \& Cie, X-Shape Version 1.01: Program for the crystal optimization for numerical absorption correction, STOE \& Cie GmbH, Darmstadt, Germany (1996).

[48] STOE \& Cie, X-Red Version 1.08: Program for data reduction and absorption correction, STOE \& Cie GmbH, Darmstadt, Germany (1996).

[49] CCDC 285300 (1), 285301 (2), 280700 (3) and 295465 (4) contains the supplementary crystallographic data for this paper. These data can be obtained free of charge via www.ccdc.cam.ac.uk/conts/retrieving.html (or from the CCDC, 12 Union Road, Cambridge CB2 1EZ, UK; fax: +44 1223 336033; e-mail: deposit@ccdc.cam.ac.uk). 